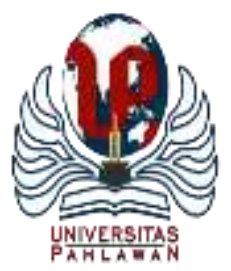

Edukatif : Jurnal Ilmu Pendidikan Volume 3 Nomor 6 Tahun 2021 Halm 4671 - 4682 EDUKATIF: JURNAL ILMU PENDIDIKAN

Research \& Learning in Education

https:/ledukatif.org/index.php/edukatif/index

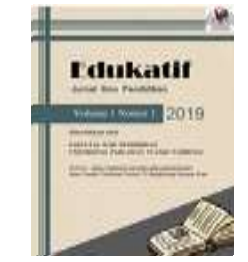

\title{
Analisis Latar Belakang Akademik dan Sosial Mahasiswa Pendidikan Bahasa dan Sastra Indonesia
}

\author{
Mashud Syahroni $^{1 凶}$, Fifit Firmadhani $^{2}$ \\ Universitas Tidar, Indonesia ${ }^{1,2}$ \\ E-mail : syahronifkip@untidar.ac.id ${ }^{1}$, fifitfirmadhani@untidar.ac.id $^{2}$
}

\begin{abstract}
Abstrak
Peminat program studi Pendidikan Bahasa dan Sastra Indonesia Universitas Tidar mengalami tren penurunan sehingga perlu peningkatan mutu pendidikan salah satunya pada proses pembelajaran bermutu dengan analisis karakteristik mahasiswa. Tujuan penelitian ini untuk menganalisis dan mendeskripsikan karakteristik mahasiswa prodi PBSI. Penelitian ini merupakan penelitian deskriptif dengan pendekatan kuantitatif. Subyek penelitian adalah mahasiswa program studi PBSI Universitas Tidar angkatan 2018-2020 dan sampel ditentukan menggunakan teknik stratified proportional random sampling. Pengumpulan data dengan angket dan dianalisis menggunakan teknik analisis statistik deskriptif dengan tabel tunggal. Hasil penelitian yaitu latar belakang akademik mahasiswa program studi PBSI merupakan lulusan jenjang sekolah menengah berjenis sekolah menengah atas dengan jurusan ilmu pengetahuan sosial. Alasan pemilihan prodi PBSI karena minat dan keinginan menjadi guru pegawai negeri sipil. Alasan pemilihan prodi PBSI juga karena faktor lokasi dan status perguruan tinggi negeri dari Universitas Tidar. Sedangkan latar belakang sosial mahasiswa program studi PBSI berasal dari masyarakat daerah Magelang dan sekitarnya. Ditinjau dari aspek sosial ekonomi mahasiswa berasal dari golongan ekonomi menengah bawah dengan pekerjaan orangtua mayoritas sebagai petani dan buruh. Proses pembelajaran bermutu perlu disesuaikan dengan latar belakang akademik dan sosial mahasiswa PBSI tersebut.
\end{abstract}

Kata Kunci: Latar belakang akademik, latar belakang sosial, mahasiswa.

\begin{abstract}
Student interest in the Pendidikan Bahasa dan Sastra Indonesia study program at Universitas Tidar is experiencing a downward trend so that it's necessary to improve the quality of education, one of which is in the quality of learning process by analyzing student characteristics. The purpose of this study was to analyze and describe the characteristics of students of the PBSI study program. This research is descriptive research with a quantitative approach. The research subjects were students of the PBSI University Tidar 2018-2020 and the sample was determined using the stratified proportional random sampling technique. Collecting data with a questionnaire and analyzed using descriptive statistical analysis techniques with a single table. The research results showed that the academic background of the PBSI study program students is high school graduates with a high school type majoring in social sciences. The reason for choosing the PBSI study program was because of the interest and desire to become a civil servant teacher. Another reason is the location and status of state universities. The social background of the students of the PBSI study program is the Magelang community and its surroundings. They come from the lower middle-class economy with parents working as farmers and laborers. The quality learning process needs to be adjusted to the academic and social backgrounds of the PBSI students.
\end{abstract}

Keywords: the academic background, the social background, students.

Copyright (c) 2021 Mashud Syahroni, Fifit Firmadhani

$\triangle$ Corresponding author:

Email : syahronifkip@untidar.ac.id

DOI : https://doi.org/10.31004/edukatif.v3i6.1492

ISSN 2656-8063 (Media Cetak)

ISSN 2656-8071 (Media Online)

Edukatif : Jurnal Ilmu Pendidikan Vol 3 No 6 Tahun 2021 p-ISSN 2656-8063 e-ISSN 2656-8071 
4672 Analisis Latar Belakang Akademik dan Sosial Mahasiswa Pendidikan Bahasa dan Sastra IndonesiaMashud Syahroni, Fifit Firmadhani

DOI: https://doi.org/10.31004/edukatif.v3i6.1492

\section{PENDAHULUAN}

Perkembangan pendidikan semakin hari semakin pesat. Hal tersebut karena masyarakat mulai sadar akan pentingnya pendidikan bagi kehidupan. Kebutuhan akan pendidikan yang berkualitas menjadi tuntutan masayarakat saat ini. Perkembangan era yang sudah memasuki revolusi industri 4.0 dan menuju masyarakat 5.0 membutuhkan individu-individu unggul dalam masyarakat. Salah satu keunggulan individu dapat diperoleh melalui pendidikan yang berkualitas. Pendidikan berkualitas tidak hanya pada jenjang pendidikan dasar dan menengah saja. Kesadaran masyarakat untuk menempuh pendidikan pada jenjang perguruan tinggi semakin meningkat. Dampaknya persaingan perguruan tinggi dalam kualitas pendidikan juga sangat kompetitif. Universitas Tidar merupakan salah satu kampus dengan predikat perguruan tinggi negeri baru. Sebagai perguruan tinggi negeri baru maka Universitas Tidar menjadi alternatif pilihan masyarakat untuk melanjutkan pendidikan. Salah satu program studi unggulan yang ada di Universitas Tidar adalah Program Studi Pendidikan Bahasa dan Sastra Indonesia (PBSI).

Persaingan masuk prodi PBSI relatif kompetitif dibanding program studi lain. Akan tetapi dibalik kondisi yang terlihat relatif baik tersebut terdapat indikasi tren peminat yang menurun pada penerimaan mahasiswa baru dalam tiga tahun terakhir. Meskipun pada jumlah mahasiswa yang diterima mengalami kenaikan tetapi peminat menurun dan mahasiswa yang diterima tetapi tidak registrasi masuk mengalami peningkatan. Kondisi tersebut juga diperkuat dengan fakta bahwa setiap tahun angkatan terdapat mahasiswa baru yang memutuskan keluar atau berhenti pada semester pertama dan kedua. Menghadapi tantangan tersebut pengelola program studi PBSI dapat melakukan berbagai langkah untuk mengembalikan minat masyarakat. Salah satu aspek yang perlu dilakukan perbaikan dan peningkatan adalah aspek mutu pendidikan di prodi PBSI. Kepuasan pelanggan yaitu masyarakat menjadi tujuan akhir dari mutu pendidikan. Kepuasan masyarakat yang tercapai maka akan mengembalikan minat masyarakat untuk memilih prodi PBSI dalam melanjutkan pendidikannya.

Salah satu cara memastikan mutu pendidikan tetap terjaga dengan baik menurut (Basyar, 2016) adalah mengadakan kontrol yang baik atau sering disebut sebagai quality control. Konsep ini berorientasi pada output untuk memastikan apakah mutu yang dihasilkannya sudah sesuai dengan standar yang ingin dicapai. Output dari pendidikan yaitu lulusan dari lembaga pendidikan. Lulusan yang berkualitas sesuai harapan masyarakat menjadi standar mutu suatu lembaga pendidikan. Banyak aspek yang harus melalui quality control salah satunya adalah proses pembelajaran. (Latuconsina, 2018) mengemukakan bahwa faktor-faktor penentu dalam manajemen mutu terpadu di perguruan tinggi adalah proses pembelajaran, kurikulum program studi, sumber daya manusia, kemahasiswaan, prasarana dan sarana, suasana akademik, keuangan, penelitian dan publikasi, pengabdian pada masyarakat dan tata kelola. Proses pembelajaran menjadi penting dalam standar mutu karena merupakan proses membentuk output lulusan.

Meskipun pembelajaran bukan satu satunya tolak ukur kesuksesan pendidikan di perguruan tinggi. Akan tetapi berawal dari kualitas pembelajaran yang baik akan menghasilkan mahasiswa dengan modal kemampuan daya pikir dan kompetensi untuk bersaing pada bidang lain. Pembelajaran yang berkualitas adalah pembelajaran yang dapat mengembangkan semua potensi peserta didik menjadi optimal. Maka proses pembelajaran harus sesuai dengan karakteristik yang dimiliki mahasiswa tersebut. Pembelajaran yang sesuai karateristik dan latar belakang yang dimiliki mahasiswa akan menjadikan pembelajaran yang menyenangkan. Pembelajaran yang menyenangkan akan membuat mahasiswa mampu mengelaborasi berbagai macam pengalaman dan potensi yang ada pada dirinya. Guna mewujudkan pembelajaran berkualitas yang baik maka dosen sebagai pendidik harus membuat strategi dan metode pembelajaran yang dapat memenuhi tuntutan tersebut. Perencanaan pembelajaran dengan analisis karakteristik mahasiswa perlu dilakukan.

Karakteristik merupakan ciri khas dari individu yang berbeda dari individu lain. Karakteristik terkait dengan aspek aspek yang menjadi dasar atau latar belakang perilaku individu dalam bidang tertentu. 
4673 Analisis Latar Belakang Akademik dan Sosial Mahasiswa Pendidikan Bahasa dan Sastra IndonesiaMashud Syahroni, Fifit Firmadhani

DOI: https://doi.org/10.31004/edukatif.v3i6.1492

Kaitannya dengan peserta didik maka karakteristik peserta didik dapat berarti sebagai ciri kualitas pada setiap individu peserta didik yang meliputi kemampuan akademik, usia dan tingkat kedewasaan, motivasi belajar, pengalaman, keterampilan, psikomotorik, kemampuan kerjasama, serta kemampuan sosial. Karakteristik peserta didik menjadi salah satu aspek penting dalam perencanaan pendidikan maupun proses pembelajaran. Setiap peserta didik pasti mempunyai karakteristik yang khas dan berbeda dengan peserta didik yang lain. Sehingga pendidik perlu mengidentifikasi kemampuan awal dan karateristik peserta didik. Analisis terhadap karakteristik peserta didik merupakan jembatan bagi kesenjangan pelaksanaan proses pembelajaran dan mutu lulusan. Hasil analisis karakteristik dan kemampuan awal akan memberikan gambaran kondisi riil peserta didik. Pengetahuan akan kondisi riil peserta didik memudahkan pendidik menentukan pemberian segala sesuatu yang berguna dalam rangka pencapaian kemampuan akhir yang diharapkan.

Proses analisis karakteristik mahasiswa belum diterapkan di prodi PBSI. Proses pembelajaran dari tahun ke tahun dilakukan dengan metode dan strategi yang sama. Padahal banyak perubahan yang terjadi terutama mahasiswa yang diterima karena perubahan status menjadi perguruan tinggi negeri. Sehingga mahasiswa yang menempuh pendidikan tidak lagi berasal dari latar belakang yang sama ketika masih berstatus perguruan tinggi swasta. Perlu penyesuaian metode dan strategi pembelajaran untuk mencapai hasil pembelajaran yang optimal kembali. (Meriyati, 2015) mengemukakan bahwa tujuan dari identifikasi kemampuan awal dan karakteristik peserta didik mempunyai yaitu: (1) Memperoleh informasi yang lengkap dan akurat berkenaan dengan kemampuan serta karakteristik awal siswa sebelum mengikuti program pembelajaran tertentu. (2) Menyeleksi tuntutan, bakat, minat, kemampuan, serta kecenderungan peserta didik berkaitan dengan pemilihan program-program pembelajaran tertentu yang akan diikuti mereka. (3) Menentukan desain program pembelajaran dan atau pelatihan tertentu yang perlu dikembangkan sesuai dengan kemampuan awal peserta didik.

Analisis karakteristik peserta didik idealnya dilakukan sebelum pembelajaran dilaksanakan. (Taufik, 2019) mengemukakan karakteristik peserta didik yang perlu dipahami pendidik yaitu latar belakang akademik dan faktor-faktor sosial. Latar belakang akademik meliputi jumlah peserta didik, latar belakang peserta didik, indeks prestasi, tingkat intelegensi, keterampilan membaca, nilai ujian, kebiasaan belajar/gaya belajar, minat belajar, harapan peserta didik, lapangan kerja harapan. Sedangkan faktor sosial meliputi usia, kematangan, rentangan perhatian, bakat, hubungan sesama peserta didik, keadaan sosial ekonomi. Faktor sosial peserta didik tersebut sering tidak diperhatikan para pendidik ketika menganalisis kemampuan awal peserta didik. Padahal faktor sosial tersebut mempunyai peran yang siginifikan dalam proses pembelajaran. Keberlangsungan pembelajaran sangat terkait dengan dukungan dan kondisi sosial disekitar peserta didik.

Mahasiswa merupakan peserta didik yang menempuh pendidikan di perguruan tinggi. Keberadaan mahasiswa dalam pembelajaran tidak berbeda dengan peserta didik pada jenjang sebelumnya. Diperlukan analisis karakteristik dan kemampuan awal untuk mengoptimalkan segala kegiatan yang diselenggarakan di perguruan tinggi sebagai bekal bagi mahasiswa. Latar belakang akademik mahasiswa dapat dengan mudah diketahui oleh dosen sebagai pendidik. Sistem seleksi masuk perguruan tinggi masih menggunakan sistem tes dan penelusuran bakat akademik pada jenjang sekolah menengah. Sistem tersebut memungkinkan mahasiswa yang diterima di sebuah perguruan tinggi rata-rata akan memiliki latar belakang akademik yang sama. Akan tetapi latar belakang akademik dari data akademik masih belum dimanfaatkan secara baik guna pendukung menyusun pembelajaran.

Keterbatasan waktu dan kemampuan yang berbeda tiap individu dosen menjadikan analisis karakteristik mahasiswa jarang atau bahkan tidak dilakukan oleh mayoritas dosen prodi PBSI. Dampaknya pembelajaran di perguruan tinggi yang dilakukan oleh dosen mayoritas kurang bervariasi. Padahal mahasiswa di perguruan tinggi lebih bervariasi karakteristik yang dimiliki daripada jenjang sekolah dibawahnya. Terlebih prodi PBSI Universitas Tidar yang merupakan perguruan tinggi baru. Masyarakat yang menempuh pendidikan dari tahun 
4674 Analisis Latar Belakang Akademik dan Sosial Mahasiswa Pendidikan Bahasa dan Sastra IndonesiaMashud Syahroni, Fifit Firmadhani

DOI: https://doi.org/10.31004/edukatif.v3i6.1492

ke tahun pasti mengalami perubahan. Sehingga seharusnya memerlukan inovasi yang lebih banyak agar proses pembelajaran dapat mengembangkan potensi mahasiswa sebagai peserta didik.

Berbeda dengan latar belakang akademik, latar belakang sosial yang kurang diperhatikan oleh pendidik di perguruan tinggi. (Djalil, Kasim, Arif, Astriyanti, \& Astuti, 2014) menemukan latar belakang peserta didik dalam hal ini sosial budayanya berpengaruh terhadap kinerja akademik peserta didik jauh lebih kuat daripada pengaruh proses pembelajaran yaitu strategi dan teknik pembelajaran yang dilakukan oleh guru. Selain itu faktor demografis dan psikologis berpengaruh pada tingkat keberhasilan peserta didik. Prestasi dalam kinerja akademik dipengaruhi aspirasi dan harapan tinggi orang tua siswa dan rekan-rekan terhadap pentingnya pendidikan. Aspirasi dan harapan lingkungan sosial tersebut biasanya akan mempengaruhi mahasiswa dalam memilih jurusan. Proses pemilihan jurusan tersebut berdampak pada motivasi belajar mahasiswa. Hasil penelitian (Zanthy, 2016) menunjukkan pengaruh motivasi belajar mahasiswa ditinjau dari latar belakang pilihan jurusan terhadap kemampuan berpikir kritis matematis mahasiswa. Sehingga dasar pemilihan jurusan seorang mahasiswa juga perlu dianalisis. Sebaran pemilihan jurusan akan memetakan potensi mahasiswa terkait motivasinya dalam mengikuti pembelajaran.

Aspek latar belakang ekonomi keluarga juga berpengaruh pada perilaku seseorang termasuk ketika mengikuti pendidikan. Penelitian (Ridha, Fajri, \& Haikal, 2019) menemukan hubungan antara variabel latar belakang dengan kesadaran lingkungan mahasiswa. Lima variabel sosiografi yang memiliki hubungan dengan kesadaran lingkungan yakni variabel pekerjaan ayah, pekerjaan ibu, penghasilan ayah, penghasilan ibu dan tempat tinggal. Selain itu pengalaman mahasiswa bekerja dan pendidikan sebelumnya juga berpengaruh pada proses pembelajaran. (Manurung \& Hamidi, 2017) mengungkapkan latar belakang pendidikan dan status bekerja berpengaruh signifikan terhadap pemahaman akuntansi. Berdasar berbagai penelitian tersebut maka faktor sosial dalam karakteristik peserta didik yang digunakan dalam penelitian antara lain asal daerah, pekerjaan orang tua, status pekerjaan, dan latar belakang dalam memilih jurusan.

Oleh karena itu, tujuan penelitian adalah untuk menganalisis dan mendeskripsikan karakteristik mahasiswa program studi Pendidikan Bahasa dan Sastra Indonesia, Universitas Tidar. Analisis karakteristik diperlukan oleh dosen prodi PBSI sebagai dasar dalam melakukan pengembangan kualitas pembelajaran khususnya dan kualitas pendidikan umumnya. Karakteristik mahasiswa selama tiga tahun kebelakang dapat dipakai sebagai gambaran tren mahasiswa yang diterima di prodi PBSI. Berdasarkan tren karakteristik mahasiswa tersebut maka dapat diperoleh manfaat berupa deskripsi karakteristik mahasiswa yang meliputi latar belakang sosial, ekonomi, dan kondisi internal mahasiswa. Analisis karakteristik mahasiswa akan berguna untuk merumuskan strategi dan metode pembelajaran yang sesuai dan dapat diterima mahasiswa. Penerimaan yang baik saat pembelajaran akan meningkatkan kualitas pembelajaran. Kualitas pembelajaran yang baik akan memperkuat mutu prodi PBSI melalui prestasi dan kualitas lulusan. Pada akhirnya akan berdampak pada kepercayaan masyarakat tumbuh dengan kualitas lulusan prodi PBSI. Kepercayaan yang kuat akan mendorong meningkatnya peminat yang mendaftar pada prodi PBSI sehingga mutu dan eksistensi prodi PBSI akan selalu terjaga.

\section{METODE PENELITIAN}

Penelitian ini merupakan penelitian deskriptif dengan pendekatan kuantitatif. Penelitian deskriptif merupakan penelitian yang menggambarkan keadaan subyek atau objek penelitian pada suasana alamiah berdasarkan fakta yang tampak. Tujuan penelitian adalah mendeskripsikan karakteristik mahasiswa yang menempuh kuliah di program studi PBSI Universitas Tidar berdasarkan latar belakang akademik dan faktor sosialnya. Metode kuantitatif yang dipakai adalah metode survei. Metode survei dilakukan dengan pengambilan sampel dari populasi melalui penggunaan kuesioner sebagai alat pengumpul data yang pokok. Metode survei yang dilakukan tergolong survey cross sectional, yaitu survey yang dilakukan hanya pada saat tertentu dan tanpa memberikan perlakuan pada subyek yang diteliti. 
4675 Analisis Latar Belakang Akademik dan Sosial Mahasiswa Pendidikan Bahasa dan Sastra IndonesiaMashud Syahroni, Fifit Firmadhani

DOI: https://doi.org/10.31004/edukatif.v3i6.1492

Subyek penelitian adalah mahasiswa program studi PBSI Universitas Tidar angkatan 2018 sampai 2020 dengan jumlah total 353 mahasiswa. Penentuan sampel menggunakan teknik stratified proportional random sampling. Populasi terdiri dari mahasiswa angkatan 2018, 2019 dan 2020 sehingga pengambilan sampel dilakukan acak dan proporsional mewakili setiap angkatan. Jumlah sampel ditentukan menggunakan rumus slovin dengan taraf signifikansi $\alpha=0,05$. Perhitungan jumlah sampel yaitu:

$$
n=\frac{N}{1+N \alpha^{2}}=\frac{353}{1+353 \cdot(0,05)^{2}}=187,52=188
$$

Jumlah sampel adalah 188 mahasiswa (pembulatan ke atas). Sampel tersebar dalam populasi yang terbagi kelompok strata angkatan. Agar pengambilan sampel proporsional dan representatif maka ditentukan sebaran sampel pada tiap angkatan sebagai berikut.

\section{Tabel 1}

Penentuan jumlah sampel penelitian

\begin{tabular}{ccc}
\hline Angkatan & Jumlah & Sampel \\
\hline 2018 & 103 & 55 \\
\hline 2019 & 121 & 64 \\
\hline 2020 & 129 & 69 \\
\hline Total & $\mathbf{3 5 3}$ & $\mathbf{1 8 8}$
\end{tabular}

Data yang dikumpulkan merupakan data primer langsung dari subjek penelitian. Pengumpulan data menggunakan instrumen penelitian berupa angket atau kuisioner. Angket berisi sejumlah pertanyaan tertulis yang digunakan untuk memperoleh informasi dari subyek penelitian terkait karakteristik mahasiswa yang terdiri dari latar bekalang akademik dan faktor sosial. Guna mengukur keabsahan instrumen maka instrumen kuisioner tidak diuji coba ke subyek penelitian tetapi menggunakan uji validitas konstruk oleh ahli.

Teknik analisis data yang digunakan adalah statistik deskriptif. Data yang dikumpulkan dari sampel menggunakan kuisioner selanjutnya dianalisis menggunakan analisa tabel tunggal. Analisa tabel tunggal dilakukan dengan mendistribusi variabel penelitian dalam kategori yang dilakukan atas dasar frekuensi. Tabel tunggal terdiri dari kolom yaitu jumlah frekuensi dan presentasi setiap kategori. Setelah disusun, diurutkan dan dibagi dalam kategori maka diketahui frekuensi dan prosentasi. Berdasarkan frekuensi dan prosentase tersebut kemudian dianalisis dan diintrepretasikan melalui kalimat secara jelas dan terperinci.

\section{HASIL DAN PEMBAHASAN PENELITIAN}

Karakteristik mahasiswa program studi PBSI Universitas Tidar ditinjau dalam dua kategori karakteristik yaitu latar belakang akademik dan latar belakang faktor sosial. Aspek karakteristik pertama yaitu terkait dengan latar belakang asal sekolah. Berdasarkan analisis data didapatkan bahwa mahasiswa program studi PBSI Universitas Tidar angkatan 2018 sampai 2020 mayoritas berasal dari sekolah menengah berjenis sekolah menengah atas. Secara rinci terdapat $66 \%$ mahasiswa berasal dari SMA umum, sedangkan $20 \%$ mahaisswa dari sekolah berjenis SMK dan sebanyak 14\% mahasiswa berasal dari sekolah menengah berbasis keagamaan seperti Madrasah Aliyah.

Ditinjau dari aspek latar belakang jurusan di sekolah menengah didapatkan hasil bahwa lebih banyak mahasiswa yang memiliki latar belakang jurusan ilmu pengetahuan sosial daripada jurusan ilmu pengetahuan alam. Rincian persentase menunjukkan 54\% mahasiswa memiliki latar belakang jurusan IPS dan 24\% mahasiswa memiliki latar belakang jurusan IPA. Sedangkan sisanya sebanyak 3\% mahasiswa memiliki latar belakang jurusan bahasa. Sehingga latar belakang jurusan pada sekolah menengah yang dominan pada mahasiswa yang diterima di PBSI Universitas Tidar selama tahun 2018 sampai 2020 adalah jurusan ilmu pengetahuan sosial. 
4676 Analisis Latar Belakang Akademik dan Sosial Mahasiswa Pendidikan Bahasa dan Sastra IndonesiaMashud Syahroni, Fifit Firmadhani

DOI: https://doi.org/10.31004/edukatif.v3i6.1492

Latar belakang jenis sekolah menegah dan penjurusannya tersebut dapat digunakan sebagai gambaran kemampuan awal mahasiswa yang diterima pada tahun 2018-2020. Pada aspek keilmuan maka mahasiswa belum mempunyai kemampuan awal keilmuan bahasa dan sastra Indonesia yang memadai. Hanya sekitar 3\% mahasiswa yang berlatar jurusan bahasa. Sejalan dengan fakta tersebut, pada aspek pengetahuan mahasiswa terkait materi yang akan dipelajari ketika kuliah di prodi PBSI juga tergolong rendah. Terdapat lebih dari 75\% mahasiswa yang menjawab pertanyaan mengetahui materi yang akan dipelajari sebelum mendaftar prodi PBSI dengan jawaban tidak mengetahui. Mahasiswa yang menyatakan mengetahui materi pembelajaran yang akan dipelajari pada saat kuliah di prodi PBSI hanya 23\%. Sehingga kemampuan awal mahasiswa angkatan 2018 2020 prodi PBSI Untidar relatif masih belum mencukupiditinjau dari jenis jurusan sekolah menengah dan persepsi mahasiswa terhadap bekal kemampuan.

Karakteristik kemampuan awal mahasiswa sangat terkait dengan kesiapan mahasiswa dalam menerima dan mengikuti pembelajaran. Setiap mahasiswa merupakan peserta didik yang dalam dirinya telah mempunyai berbagai pengalaman, kondisi dan potensi berbeda-beda. Karakteristik kemampuan awal tersebut perlu diketahui pendidik sebelum memulai pembelajaran. Metode dan strategi pembelajaran yang digunakan tergantung prasyarat pengetahuan yang telah dimiliki peserta didik. Ketepatan penggunaan metode dan strategi pembelajaran akan berdampak pada hasil yang diraih peserta didik. Gambaran karakteristik kemampuan awal digunakan untuk mengukur dampak perubahan dari hasil belajar.

Pada jenjang perguruan tinggi pembelajaran menggunakan pendekatan pembelajaran andragogi yang menganggap mahasiswa manusia dewasa sangat penting diperoleh gambaran karakteristik kemampuan awal mahasiswa. Banyak penelitian mengungkapkan pentingnya karakteristik kemampuan awal, misalnya dalam bidang matematika ditemukan pengaruh yang signifikan antara kemampuan awal terhadap kemampuan komunikasi matematika. (Sara Fitriani; Nurhanurawati; Coesamin;, 2021) Tidak hanya dalam matematika, kemampuan awal berpengaruh signifikan pada bidang fisika (Astuti, 2015) dan juga pada bidang bahasa. Sehingga perbedaan karakteristik kemampuan awal yang ada pada mahasiswa prodi PBSI Untidar perlu dikurangi.

Salah satu program yang layak menjadi solusi dalam mengatasi karakteristik kemampuan awal yang belum sesuai yaitu program matrikulasi. Matrikulasi adalah program pembelajaran untuk peserta didik baru yang bertujuan untuk menyetarakan kompetensi bagi program studi yang memiliki peserta didik dengan keberagaman latar belakang pendidikan sebelumnya. Pada banyak bidang keilmuan program matrikulasi menunjukkan hasil yang signifikan dalam meningkatkan dan menyeragamkan kemampuan awal peserta didik.

Pada bidang matematika kegiatan matrikulasi mampu meningkatkan kemampuan matematika dasar mahasiswa dengan nilai efektivitas 39\%. (Muhammad, 2021). Pada pendidikan bahasa arab keikutsertaan terhadap program matrikulasi berkontribusi sebanyak 50,6\% terhadap kemampuan berbahasa arab mahasiswa baru (Afaria, 2020). Begitu pula pada bidang bahasa inggris program matrikulasi efektif untuk meningkatkan kinerja mahasiswa (Djalil et al., 2014). Melalui materi matrikulasi yang berkaitan dengan perkuliahan dan materi perkuliahan sangat penting bagi mahasiswa baru dalam mendapatkan bekal sikap, pengetahuan, dan ketrampilan sebelum mengikuti perkuliahan. Selain itu materi yang diperoleh selama matrikulasi memberi manfaat ketika mereka mengikuti perkuliahan. (Syahadati, Sari, \& Inggris, 2018)

Karakteristik kemampuan awal mahasiswa prodi PBSI angkatan 2018-2020 selain dari aspek jurusan sekolah menengah juga dilihat dari aspek jalur penerimaan mahasiswa baru. Jalur penerimaan mahasiswa baru mempunyai hubungan yang signifikan dengan prestasi mahasiswa dalam bidang akademik. Meskipun bukan merupakan satu satunya faktor yang berpengaruh dalam bidang akademik mahasiswa, karakteristik mahasiswa pada tiap jalur penerimaan peserta didik perlu diketahui. Penelitian para ahli menunjukkan jalur masuk penerimaan mahasiswa baru berpengaruh pada prestasi akademik dan lama studi. Prestasi akademik dan lama studi mahasiswa jalur SNMPTN lebih tinggi daripada jalur SBMPTN dan Mandiri. Sedangkan, prestasi akademik dan lama studi mahasiswa jalur SBMPTN dan Mandiri tidak berbeda secara signifikan. (Djudin, 
4677 Analisis Latar Belakang Akademik dan Sosial Mahasiswa Pendidikan Bahasa dan Sastra IndonesiaMashud Syahroni, Fifit Firmadhani

DOI: https://doi.org/10.31004/edukatif.v3i6.1492

2018). Secara hasil belajar mahasiswa jalur SBMPTN memiliki skor rata-rata hasil belajar tertinggi daripada mahasiswa jalur SNMPTN dan Mandiri. (Dewi Lestari; Herman Anis; Khaeruddin, 2018)

Terdapat tiga sistem penerimaan mahasiswa baru yang berlaku di Universitas Tidar selama tahun 20182020 yaitu seleksi nasional perguruan tinggi negeri (SNMPTN), seleksi bersama masuk perguruan tinggi negeri (SBMPTN), dan seleksi masuk mandiri Universitas Tidar (SM gelombang 1 dan gelombang 2).Dari ketiga jalur seleksi penerimaan mahasiswa baru tersebut SBMPTN dan SM Universitas Tidar menjadi dua jalur masuk paling banyak menerima mahasiswa. Mahasiswa yang melalui jalur SBMPTN sebanyak 38\% dan melalui SM Universitas Tidar sebanyak 38\% dengan rincian SM gelombang 1 29\% dan SM gelombang $29 \%$. Jalur masuk melalui SNMPTN hanya sekitar 24\% dari mahasiswa yang diterima pada tahun 2018-2020. Ditinjau dari sebaran ketiga jalur masuk penerimaan mahasiswa baru relatif merata. Diagram sebaran ketiga jalur penerimaan mahasiswa baru sebagai berikut.

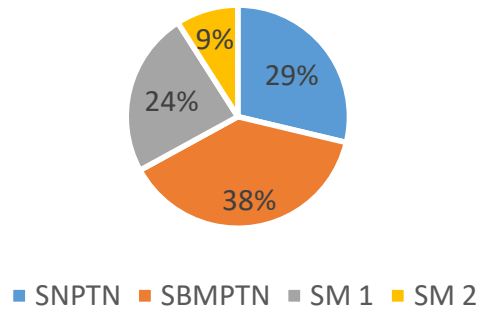

\section{Gambar 1. Diagram sebaran penerimaan mahasiswa}

Pengaruh jalur penerimaan mahasiswa baru pada bidang akademik dapat lebih detail ditinjau dari minat mahasiswa baru dari segi posisi pemilihan program studi. Pada setiap jalur penerimaan mahasiswa baru terdapat perbedaan minat mahasiswa dalam memilih prodi PBSI. Posisi prodi PBSI pada tiap jalur penerimaan mahasiswa baru dapat dikategorikan relatif bervariasi. Pada jalur SNMPTN sebanyak 83\% mahasiswa yang diterima meletakkan prodi PBSI sebagai pilihan pertama. SNMPTN merupakan seleksi nasional yang didasarkan pada prestasi akademik. Pada jalur SNMPTN calon mahasiswa merupakan peserta didik terbaik sesuai usulan sekolah dan mendapat bimbingan arahan dari guru saat memilih program studi. Sehingga pilihan akan cenderung sudah terencana dan terarah sesuai kemampuan peserta didik berdasarkan penilaian dari guru pembimbing. Kondisi tersebut yang berdampak pada prestasi akademik dan lama studi yang lebih baik daripada jalur penerimaan lain.

Kondisi berbeda pada jalur SBMPTN yang menunjukkan mahasiswa yang diterima meletakkan pilihan prodi PBSI pada pilihan kedua sebanyak $61 \%$, sedangkan pilihan pertama hanya $29 \%$, dan sisanya pada pilihan ketiga. SBMPTN merupakan jalur seleksi mahasiswa baru yang didasarkan pada hasil tes tertulis dari para calon mahasiswa. Karena kemungkinan peluang yang cukup besar maka calon mahasiswa baru akan memilih prodi yang sesuai dengan cita cita atau keinginan mereka. Letak pada urutan pilihan tersebut menunjukkan prioritas pemilihan program studi para mahasiswa pada jalur SBMPTN. Dari sebaran posisi pemilihan prodi tersebut maka prodi PBSI Universitas Tidar menjadi pilihan program studi alternatif setelah para calon mahasiswa gagal pada pilihan prodi pertama.

Kedua jalur penerimaan tersebut merupakan saringan mahasiswa baru yang cukup kompetitif. Mahasiswa yang tidak diterima melalui kedua jalur penerimaan tersebut akan berkompetisi pada seleksi yang dilaksanakan mandiri setiap perguruan tinggi. Pada jalur masuk seleksi mandiri Universitas Tidar sebagian besar mahasiswa meletakkan posisi prodi PBSI pada pilihan pertama. Pada SM gelombang 1 sebanyak 71\% mahasiswa diterima memilih prodi PBSI pada pilihan pertama, sedangkan pada SM gelombang kedua sebanyak 76\% mahasiswa yang diterima meletakkan prodi PBSI pada pilihan pertama mereka.

Pada seleksi mandiri mayoritas mahasiswa yang diterima menempatkan prodi PBSI sebagai pilihan pertama karena seleksi mandiri merupakan peluang terakhir. Sehingga pilihan mahasiswa akan lebih terbatas 
4678 Analisis Latar Belakang Akademik dan Sosial Mahasiswa Pendidikan Bahasa dan Sastra IndonesiaMashud Syahroni, Fifit Firmadhani

DOI: https://doi.org/10.31004/edukatif.v3i6.1492

dan spesifik. Sehingga kondisi tersebut memaksa mahasiswa menentukan prodi prioritas yang memiliki peluang terbesar. Secara rinci sebaran pilihan prodi PBSI pada setiap jalur penerimaan mahasiswa baru sebagai berikut.

\section{Tabel 2}

Sebaran pilihan sesuai jalur penerimaan mahasiswa baru

\begin{tabular}{lccc}
\hline Jalur Masuk & Pilihan 1 & Pilihan 2 & Pilihan 3 \\
\hline SNPTN & $83 \%$ & $17 \%$ & - \\
\hline SBMPTN & $29 \%$ & $61 \%$ & $10 \%$ \\
\hline SM 1 & $71 \%$ & $24 \%$ & $4 \%$ \\
\hline SM 2 & $76 \%$ & $12 \%$ & $12 \%$
\end{tabular}

Sebaran prioritas pilihan pada penerimaan mahasiswa baru tersebut sejalan dengan alasan pemilihan prodi PBSI yang diungkapkan oleh mahasiswa baru angkatan 2018-2020. Berdasarkan data prioritas pilihan prodi jalur SNMPTN dan SM Untidar mayoritas mahasiswa menjatuhkan pilihan pertama pada prodi PBSI. Hal tersebut berarti separuh mahasiswa menempatkan pilihan prodi PBSI pada pilihan pertama. Ditinjau dari sebaran alasan minat memilih prodi PBSI maka 51\% mahasiswa baru menyatakan sesuai dengan minat. Secara rinci sebaran alasan pemilihan prodi PBSI pada mahasiswa prodi PBSI 2018-2020 sebagai berikut.

Tabel 3

Alasan pemilihan prodi PBSI Universitas Tidar

\begin{tabular}{lc}
\hline Alasan Memilih PBSI & Presentase \\
\hline sesuai dengan minat & $51 \%$ \\
\hline keinginan menjadi guru/PNS & $21 \%$ \\
\hline sebagai pilihan alternatif lain (coba-coba) & $10 \%$ \\
\hline akreditasi prodi & $8 \%$ \\
\hline Lainnya & $9 \%$ \\
\hline
\end{tabular}

Pada posisi kedua alasan para mahasiswa memilih prodi PBSI karena keinginan untuk menjadi guru atau pegawai negeri sipil sebesar $21 \%$ mahasiswa. Sisanya memilih prodi PBSI karena hanya alternatif cobacoba, akreditasi prodi, dan beberapa alasan lain. Kondisi tersebut sama dengan hasil penelitian (Riadi, 2016) bahwa hal yang menjadi motivasi mahasiswa memilih prodi di Jurusan Bahasa dan Seni antara lain tujuannya mengembangkan minat bakat dan cita-cita ingin menjadi guru. Berdasarkan kedua alasan tersebut maka mahasiswa prodi PBSI angkatan 2018-2020 seharusnya mempunyai motivasi belajar yang tinggi. Hasil penelitian (Aziz B \& Rachmawaty, 2018) menunjukkan adanya hubungan positif yang signifikan antara variabel motivasi belajar dengan minat siswa untuk melanjutkan perguruan tinggi. Karakteritik alasan pemilihan prodi tersebut dapat digunakan sebagai modal potensi besar dalam manajemen peserta didik. Motivasi yang tinggi dalam belajar dapat menjadi prestasi belajar yang optimal jika dapat dikelola dengan baik oleh jajaran pengelolan program studi.

Selain karena alasan minat dan cita-cita mahasiswa memilih prodi PBSI juga karena faktor Universitas Tidar. Alasan geografis letak kampus Universitas Tidar menjadi alasan bagi sebanyak $43 \%$ mahasiswa baru prodi PBSI yang diterima pada tahun 2018-2020. Alasan kedua terbesar dalam pemilihan Universitas Tidar sebagai pilihan kampus adalah status perguruan tinggi negeri. Alasan sisanya secara merata alasan pemilihan Universitas Tidar adalah karena mengikuti arahan kerabat dekat, kemudian karena akreditasi perguruan tinggi, alternatif pilihan, biaya pendidikan dan adanya prodi yang diminati. Secara rinci alasan pemilihan Universitas Tidar pada mahasiswa prodi PBSI tahun 2018-2020 sebagai berikut.

\section{Tabel 4}

Alasan penilihan Universitas Tidar Alasan Memilih Untidar

Lokasi dekat dengan tempat tinggal

Status Perguruan Tinggi Negeri

Presentase

$43 \%$

$18 \%$


4679 Analisis Latar Belakang Akademik dan Sosial Mahasiswa Pendidikan Bahasa dan Sastra Indonesia Mashud Syahroni, Fifit Firmadhani

DOI: https://doi.org/10.31004/edukatif.v3i6.1492

\begin{tabular}{ll}
\hline $\begin{array}{l}\text { Mengikuti Keinginan/ Arahan Referensi dari orang } \\
\text { tua/keluarga/saudara/kerabat/tetangga }\end{array}$ & $11 \%$ \\
\hline Keinginan Minat Diri Sendiri & $7 \%$ \\
\hline Akreditasi Untidar & $6 \%$ \\
\hline Sebagai pilihan alternatif lain (coba-coba) & $6 \%$ \\
\hline Biaya Pendidikan & $5 \%$ \\
\hline Ada prodi yang diminati & $3 \%$
\end{tabular}

(Ridha et al., 2019) mengatakan ada pengaruh antara lokasi sekolah, promosi sekolah, persepsi, dan lingkungan teman sebaya terhadap minat siswa memilih jurusan. Hal yang sama juga diungkapkan oleh (Aryati, 2019) bahwa kualitas, lokasi, dan biaya berpengaruh positif dan signifikan terhadap keputusan kuliah. Lokasi Universitas Tidar secara geografis berada diantara kota besar di Jawa Tengah. Lokasi tersebut cukup strategis karena dapat menjadi pilihan masyarakat dalam menempuh pendidikan tanpa harus merantau ke kota kota besar seperti Semarang ataupun Yogyakarta. Keuntungan geografis lokasi didukung dengan status perguruan tinggi negeri. Status perguruan tinggi negeri tersebut menambah minat mahasiswa dalam memilih Universitas Tidar.

Dengan demikian latar belakang akademik mahasiswa prodi PBSI angkatan 2018-2020 sebagian besar merupakan lulusan jenjang sekolah menengah berjenis sekolah menengah atas. Jurusan yang dominan sebagai latar belakang mahasiswa prodi PBSI adalah jurusan ilmu pengetahuan sosial. Jalur penerimaan mahasiswa tersebar merata mulai dari SNMPTN, SBMPTN dan seleksi mandiri Universitas Tidar. Mahasiswa yang memilih prodi PBSI pada pilihan pertama saat seleksi penerimaan adalah para mahasiswa jalur SNMPTN dan SM Untidar. Alasan mahasiswa memilih prodi PBSI karena memang minat pada prodi yang bersangkutan dan alasan cita cita menjadi guru pegawai negeri sipil. Selain karena faktor keberadaan prodi mahasiswa memilih Untidar juga karena faktor lokasi dan status perguruan tinggi yang sudah menjadi negeri.

Aspek karakteristik yang kedua adalah latar belakang sosial. Latar belakang sosial dari hasil analisis data menunjukkan fakta-fakta yang saling terkait dengan latar belakang akademik. Latas belakang sosial pertama adalah terkait latar belakang daerah asal. Latar belakang tempat tinggal atau daerah asal mahasiswa menguatkan alasan-alasan yang dikemukakan mahasiswa dalam memilih prodi PBSI dan Universitas Tidar.

Daerah asal mahasiswa prodi PBSI angkatan 2018-2020 didominasi daerah Magelang dan sekitarnya. Lebih dari 65\% mahasiswa merupakan penduduk yang bertempat tinggal di daerah meliputi Kota Magelang, Kabupaten Magelang, Kabupaten Temanggung, dan Kabupaten Purworejo. Keempat daerah tersebut berada dalam satu kawasan yang relatif dapat ditempuh dalam waktu kurang dari satu jam perjalanan darat. Sehingga secara akses lokasi Universitas Tidar terjangkau dan sarana prasarana akses mudah. Selain itu juga Univeritas Tidar menjadi satu satunya kampus negeri yang ada di wilayah tersebut. Kondisi tersebut menjadikan Universitas Tidar sebagai kampus alternatif dengan jarak dan peluang kompetitif yang terjangkau seuai dengan minat mahasiswa.

Aspek ekonomi juga mempunyai hubungan yang cukup berpengaruh pada pemilihan Universitas Tidar yang mempertimbangkan lokasi dan status perguruan tinggi. Sebagian besar mahasiswa berasal dari keluarga dengan pekerjaan petani, buruh, dan wirausaha. Ketiga pekerjaan tersebut masih cukup rentan mengalami ketidakstabilan ekonomi.

Tabel 5

Jenis pekerjaan orangtua mahasiswa

\begin{tabular}{lr}
\hline Pekerjaan & Prosentase \\
\hline Petani & $24 \%$ \\
\hline Buruh & $17 \%$ \\
\hline PNS & $15 \%$ \\
\hline Pegawai Swasta & $13 \%$ \\
\hline Wirausaha & $13 \%$ \\
\hline
\end{tabular}

Edukatif : Jurnal Ilmu Pendidikan Vol 3 No 6 Tahun 2021 p-ISSN 2656-8063 e-ISSN 2656-8071 
4680 Analisis Latar Belakang Akademik dan Sosial Mahasiswa Pendidikan Bahasa dan Sastra Indonesia Mashud Syahroni, Fifit Firmadhani

DOI: https://doi.org/10.31004/edukatif.v3i6.1492

\begin{tabular}{ll} 
Pedagang & $9 \%$ \\
\hline Lain lain & $8 \%$
\end{tabular}

Dengan kondisi pekerjaan yang sebagian besar tergolong menengah ke bawah secara pendapatan maka pilihan perguruan tinggi yang sudah berstatus negeri dan terjangkau jarak menjadi pilihan realitis. Biaya pendidikan, latar belakang sosial ekonomi, reputasi, dan prospek prodi mempunyai pengaruh kepada siswa sekolah menengah dalam memilih program studi sebagai tujuan kuliah. (Fikri, Mukhammad, \& Dunakhir, 2020) Semakin dekat sebuah tempat sekolah dengan tempat tinggal maka pengeluaran terkait ekonomi masih dapat dijangkau. Hasil penelitian (Amri, 2021) menyebutkan masalah biaya memiliki pengaruh yang signifikan terhadap seseorang mengambil keputusan untuk memilih salah satu lembaga pendidikan yang akan dipilihnya untuk bersekolah ataupun kuliah. Biaya pendidikan yang dikeluarkan oleh para orang tua menjadi relatif terjangkau. Pengeluaran biaya pendidikan yang terjangkau dengan status perguruan tinggi sudah negeri menjadi keunggulan Universitas Tidar bagi masyarakat Magelang dan sekitarnya.

Hasil penelitian (Imarotul Qibthiyah, 2018) menunjukkan ada pengaruh signifikan status sosial ekonomi terhadap pemilihan jurusan di perguruan tinggi. (Permanasari, 2016) juga mengungkapkan hal yang senada bahwa ada pengaruh positif dan signifikan antara latar belakang sosial ekonomi keluarga terhadap minat melanjutkan ke perguruan tinggi. Pada mahasiswa angkatan 2018-2020 prodi PBSI terdapat 66\% mahasiswa yang biaya pendidikan ditanggung oleh orang tua atau keluarga. Sedangkan hanya $32 \%$ yang ditanggung oleh berbagai macam beasiswa. Lebih mendalam dari mahasiswa yang biaya pendidikan ditanggung oleh orangtua tersebut diperoleh orangtua kesulitan dalam membiayai perkuliahan sebanyak $44 \%$ mahasiswa. Sedangkan sebanyak 56\% mahasiswa menyatakan orangtua mereka tidak kesulitan dalam membiayai perkuliahan.

Dengan demikian karakteristik mahasiswa prodi PBSI angkatan 2018-2020 ditinjau dari latar belakang sosial menunjukkan mayoritas merupakan masyarakat yang berdomisili di Magelang dan daerah penyangga sekitarnya seperti Purworejo dan Temanggung. Secra aspek ekonomi, mahasiswa PBSI Universitas Tidar angkatan 2018-2020 dapat disimpulkan sebagian berasal dari golongan ekonomi menengah bawah. Urutan teratas pekerjaan orangtua mahasiswa tersebut adalah petani dan buruh. Pembiayaan pendidikan mahasiswa mayoritas berasal dari orang tua meraka sendiri. Kondisi tersebut menyebabkan sebagian orangtua cukup kesulitan dalam membiayai pendidikan. Aspek ekonomi tersebut terkait juga dengan pemilihan Universitas Tidar dimana alasan perguruan tinggi negeri dengan akses lokasi terjangkau menjadi alasan teratas.

Keterbatasan penelitian yang dilakukan hanya pada aspek latar belakang akademik dan sosial saja. Karakteristik peserta didik terdiri dari banyak aspek. Terlebih pada jenjang pendidikan tinggi faktor yang mempengaruhi proses pembelajaran tidak hanya aspek akademik dan sosial mahasiswa saja. Sehingga diperlukan analisis karakteristik pada latar belakang yang lain misalnya faktor minat dan faktor budaya. Hasil penelitian terkait latar belakang akademik dan sosial mahasiswa prodi PBSI dapat digunakan sebagai bahan perencanaan pendidikan. Para stakeholder pemangku kebijakan baik internal maupun ekternal perguruan tinggi dapat menggunakan data untuk membuat kebijakan yang meningkatkan mutu Universitas Tidar.

\section{KESIMPULAN}

Berdasar pada analisis data dan pembahasan maka kesimpulan dari penelitian ini adalah latar belakang akademik mahasiswa prodi PBSI angkatan 2018-2020 sebagian besar merupakan lulusan jenjang sekolah menengah berjenis sekolah menengah atas dengan jurusan ilmu pengetahuan sosial. Kuantitas mahasiswa pada tiap jalur penerimaan mahasiswa baru merata. Mahasiswa yang memilih prodi PBSI pada pilihan pertama saat seleksi penerimaan adalah para mahasiswa jalur SNMPTN dan SM Untidar. Alasan mahasiswa memilih prodi PBSI sebagian besar karena minat dan keinginan menjadi guru pegawai negeri sipil. Selain itu faktor lokasi dan status perguruan tinggi negeri pada Untidar juga menjadi alasan mahasiswa menempuh pendidikan di prodi PBSI. Sedangkan latar belakang sosial menunjukkan mayoritas mahasiswa merupakan masyarakat yang berdomisili di Magelang dan daerah penyangga sekitarnya. Secara aspek ekonomi, sebagian 
4681 Analisis Latar Belakang Akademik dan Sosial Mahasiswa Pendidikan Bahasa dan Sastra IndonesiaMashud Syahroni, Fifit Firmadhani

DOI: https://doi.org/10.31004/edukatif.v3i6.1492

mahasiswa berasal dari golongan ekonomi menengah bawah dengan pekerjaan orangtua sebagai petani dan buruh. Pembiayaan pendidikan mahasiswa mayoritas berasal dari orang tua meraka sendiri. Pengelola program studi PBSI Universitas Tidar dapat menyelenggarakan program matrikulasi atau program sejenisnya. Tujuannya adalah untuk menstandarisasi kemampuan awal mahasiswa baru sehingga lebih siap dalam menerima materi perkuliahan. Hal ini karena latar belakang akademik yang relatif kurang linier dengan program studi PBSI. Selanjutnya pendidik para prodi PBSI Universitas Tidar diharapkan mampu menerapkan strategi dan metode pembelajaran yang mempertimbangkan aspek latar belakang sosial dan budaya lokal daerah Magelang. Hal ini mengingat latar belakang sosial mahasiswa merupakan masyarakat asli daerah magelang dengan taraf ekonomi menengah kebawah.

\section{DAFTAR PUSTAKA}

Afaria, Z. (2020). Pengaruh Program Matrikulasi terhadap Kemampuan Berbahasa Arab Mahasiswa Baru Pendidikan Bahasa Arab. Tatsqifiy: Jurnal Pendidikan Bahasa Arab, 1(2), 101. https://doi.org/10.30997/tjpba.v1i2.2803

Amri, U. Y. (2021). Pengaruh Biaya Pendidikan terhadap Keputusan memilih Lembaga Pendidikan. EDUKATIF : JURNAL ILMU PENDIDIKAN, 3(5), 2355-2361. https://doi.org/10.31004/edukatif.v3i5.786

Aryati, H. N. E. K. I. (2019). Pengaruh Kualitas, Lokasi dan Biaya terhadap Keputusan Kuliah di IAIN Surakarta. Edunomika, 03(02), 376-381. https://doi.org/http://dx.doi.org/10.29040/jie.v3i02.541

Astuti, S. P. (2015). Pengaruh Kemampuan Awal dan Minat Belajar terhadap Prestasi Belajar Fisika. Formatif: Jurnal Ilmiah Pendidikan MIPA, 5(1), 68-75. https://doi.org/10.30998/formatif.v5i1.167

Aziz B, A., \& Rachmawaty, L. (2018). Hubungan Motivasi Belajar, Tingkat Pendapatan Orang Tua Dengan Minat Siswa Kelas Xi Sma Negeri 1 Kamal Untuk Melanjutkan Perguruan Tinggi. Jurnal Pendidikan Ekonomi (JUPE), 6(3). https://doi.org/10.26740/jupe.v6n3.p

Basyar, S. (2016). Manajemen Mutu Pendidikan Perguruan Tinggi Keagamaan Islam Dalam Meningkatkan Kualitas Mahasiswa. Dewantara, I(01). Retrieved from http://ejournal.iqrometro.co.id/index.php/pendidikan/article/view/manajemen-mutu-pendidikanperguruan-tinggi-keagamaan islam-dalam-meningkatkan-kualitas-mahasiswa

Dewi Lestari; Herman Anis; Khaeruddin. (2018). Analisis Hasil Belajar Mahasiswa Jurusan Fisika the Analysis of Learning Outcomes of Students Department of Physics Based on Entrance (SNMPTN , Sbmptn , and Mandiri ) Universitas Negeri Makassar. Jurnal Sains Dan Pendidikan Fisika (JSPF) Jilid 14, Nomor 3. Desemberl 2018, 15-25. https://doi.org/https://doi.org/10.35580/jspf.v14i3.9943

Djalil, A., Kasim, I., Arif, A., Astriyanti, D., \& Astuti, D. S. (2014). Latar Belakang dan Kemampuan Bahasa Inggris Prodi Bahasa Inggris. Jurnal Pendidikan Bahasa, 4(2), 171-187. https://doi.org/http://dx.doi.org/10.31571/bahasa.v4i2.88

Djudin, T. (2018). Analisis Prestasi Akademik Mahasiswa Lulusan Jurusan Pendidikan Mipa Fkip Untan Ditinjau Dari Jalur Masuk (Snmptn, Sbmptn, Mandiri) Dan Program Kuliah (S-1 Reguler, S-1 Percepatan Apk). Jurnal Pendidikan Matematika Dan IPA, 9(2), 76. https://doi.org/10.26418/jpmipa.v9i2.25867

Fikri, H., Mukhammad, I., \& Dunakhir, S. (2020). Faktor-faktor yang Memengaruhi Pemilihan Program Studi Akuntansi (Studi pada mahasiswa Universitas Negeri Makassar). Bata Ilyas Journal of Accounting, 1(1), 2020-2021. https://doi.org/http://dx.doi.org/10.23960/mtk/v9i1.pp31-41

Imarotul Qibthiyah. (2018). Pengaruh Status Sosial Ekonomi Dan Teman Sebaya Terhadap Pemilihan Jurusan Di Perguruan Tinggi. JUPE, 6, 322. https://doi.org/https://doi.org/10.26740/jupe.v6n3.p\%p

Latuconsina, Z. (2018). Faktor-Faktor Penentu Manajemen Mutu Terpadu Pada Perguruan Tinggi Di Kota 
4682 Analisis Latar Belakang Akademik dan Sosial Mahasiswa Pendidikan Bahasa dan Sastra IndonesiaMashud Syahroni, Fifit Firmadhani

DOI: https://doi.org/10.31004/edukatif.v3i6.1492

Ambon. Jurnal SOSOQ, 6(1), 93-105. https://doi.org/http://dx.doi.org/10.30598/sosoq.v6i1.305

Manurung, D. M. P., \& Hamidi. (2017). Pengaruh Latar Belakang Pendidikan Dan Status Bekerja Mahasiswa Terhadap Pemahaman Akuntansi (Studi Kasus Pada Mahasiswa Prodi Akuntansi Universitas Riau Kepulauan Batam). Measurement, 11(1), 1-10. https://doi.org/https://doi.org/10.33373/mja.v11i1.1727

Meriyati. (2015). Memahami Karakteristik Anak Didik. Lampung: Fakta Press.

Muhammad, A. J. (2021). Pengaruh Matrikulasi Matematika Dasar Terhadap Peningkatan Kemampuan Matematika Dasar Pada Mahasiswa Baru Jurusan Fisika Effect of Mathematics Matriculation on The Improvement of Basic Mathematics Ability In New Student of Physics Departement. Jurnal Penelitian Pendidikan Fisika, 6(2). https://doi.org/10.36709/jipfi.v6i2.16992

Permanasari, R. H. (2016). Pengaruh Prestasi Belajar dan Latar Belakang Sosial Ekonomi Keluarga terhadap Minat Melanjutkan Ke Perguruan Tinggi Pada Siswa SMA Negeri 3 Purworejo. OIKONOMIA, 5(3), 3 6.

Riadi, B. (2016). Persepsi dan Motivasi Mahasiswa dalam Memilih Program Studi pada Jurusan Pendidikan Bahasa dan Seni. Jurnal Pesona, 2(1), 138-148. Retrieved from http://ejournal.stkipmpringsewulpg.ac.id/index.php/pesona/article/view/200

Ridha, I., Fajri, H., \& Haikal, M. (2019). Pengaruh Latar Belakang Keluarga Terhadap Kesadaran Lingkungan Mahasiswa Di Fakultas Keguruan Dan Ilmu Pendidikan .... Jurnal Geuthëe: Penelitian ..., 02(03), 346357. https://doi.org/https://doi.org/10.9992/jg.v2i3.69

Sara Fitriani; Nurhanurawati; Coesamin; (2021). Pengaruh Kemampuan Awal dan Motivasi Belajar Terhadap Kemampuan Komunikasi Matematis Siswa. Jurnal Pendidikan Matematika, 01(02), 17-23. https://doi.org/https://doi.org/10.35580/jspf.v14i3.9943

Syahadati, E., Sari, D. S., \& Inggris, B. (2018). Persepsi Mahasiswa terhadap Matrikulasi Mahasiswa Baru. Jurnal Pendidikan Bahasa, 7(1), 16-24. https://doi.org/http://dx.doi.org/10.31571/bahasa.v7i1.823

Taufik, A. (2019). Analisis Karakteristik Peserta Didik. El-Ghiroh, XVI, No. O. https://doi.org/https://doi.org/10.37092/el-ghiroh.v16i01.71

Zanthy, L. S. (2016). Pengaruh Motivasi Belajar Ditinjau Dari Latar Belakang Pilihan Jurusan Terhadap Kemampuan Berpikir Kritis Mahasiswa Di Stkip Siliwangi Bandung. Teorema, 1(1), 47. https://doi.org/10.25157/.v1i1.540 